\author{
A.Ye. Ismagulova* ${ }^{\text {iD }}$, E.F. Gerfanova \\ Sh. Ualikhanov Kokshetau University, Kokshetau, Kazakhstan, \\ *e-mail: ismainagul@mail.ru

\section{LINGUOCULTURAL PECULIARITIES \\ OF SH. UALIKHANOV'S WORKS AS REFLECTION OF NATIONAL AND HISTORICAL FLAVOR}

This article describes the results of the analysis of the works of Sh. Ualikhanov, the first Kazakh scientist, ethnographer, folklorist, educator, who transferred the knowledge about the Kazakh people, their traditions, religion, government, legends, presented the diversity of flora and fauna of Kazakhstan, the originality of the landscape, way of life and culture of the Kazakh people. The scientist's works greatly contributed to the study of the history, culture and literature of the peoples of Central Asia. His creative heritage goes beyond national identity and can be of great interest for the world science in the context of intercultural communication and intercultural education. The article presents various types of Kazakh national realia, as well as their linguocultural features in the works of Sh. Ualikhanov. Realias are words and phrases that name objects, phenomena, objects characteristic of the life, everyday life, culture, social and historical development of one people and unfamiliar or alien to another people, expressing national and (or) temporary flavor, which do not have exact matches in another language. A particular attention is focused on conveying features of the historical era, culture, national character.

Key words: linguocultural peculiarities, realia, intercultural education, language, culture.

\author{
А.Е. Исмагулова*, Э.Ф. Герфанова \\ Ш. Уәлиханов атындағы Көкшетау университеті, Қазақстан, Көкшетау қ., \\ *e-mail: ismainagul@mail.ru

\section{Ш. Уәлихановтың ұлттық және тарихи колоритті тасымалдаушы ретіндегі шығармаларының мингвомәдени ерекшеліктері}

Бұл мақаяада тұңғыш қазақ ғалымы, этнограф, фольклортанушы, ағартушы Ш. Уәлихановтың әлемге қазақ халқы туралы, оның Аәстүрлері, Аіні, елдің алатын орны, эпосы, аңыздары мен дастандары, сонымен қатар Қазақстанның флорасы мен фаунасының алуан түрлілігін, ландшафтының өзіндік ерекшелігін, қазақ халқының тұрмысы мен мәдениетін көрсетіп, мәлім еткен еңбектерінің талдау нәтижелері сипатталған. Ғалымның еңбектері Орта Азия халықтарының тарихын, мәдениеті мен әдебиетін зерттеуге үлкен үлес қосты. Оның шығармашылық мұрасы ұлттық шеңберден шығып, мәдениетаралық коммуникация, мәдениетаралық білім аясында әлемдік ғылымға үлкен қызығушылық тудыруы мүмкін. Мақалада Ш. Уәлиханов шығармаларындағы кейбір ұлттық мингвомәдени ерекшеліктерімен қатар, қазақ халқының ұлттық шынайылығы мен қызмет ету ерекшеліктері көрсетілген, тарихи дәуірдің, мәдениеттің, ұлттық сипаттың, мекеннің ерекшеліктерін жеткізетін шындыққа ерекше назар аударылған. Шындық, дегеніміз бір халықтың өміріне, тұрмысына, мәдениетіне, әлеуметтік-тарихи дамуына тән және басқа халыққа таныс емес заттарды, құбылыстарды, заттардың аттарын, ұлттық және/ немесе уақыттық, өзге тілдегі дәл сәйкестіктер жоқ сипаттамасын білдіреді.

Түйін сөздер: ^ингвомәдени ерекшеліктер, шындық, мәдениаралық білім, тіл, мәдениет.

\author{
А.Е. Исмагулова*, Э.Ф. Герфанова \\ Кокшетауский университет им. Ш. Уалиханова, Казахстан, г. Кокшетау, \\ *e-mail: ismainagul@mail.ru

\section{Аингвокультурологические особенности произведений Ш. Уалиханова как носителей национального и исторического колорита}

В Аанной статье описаны результаты анализа трудов Ш. Уалиханова, первого казахского ученого, этнографра, фольклориста, просветителя, который преАставил миру знания о казахском народе, его традициях, религии, государственном устройстве, эпосе, сказаниях и легендах; отразил многообразие флоры и фауны Казахстана, своеобразие ландшафта, быта и культуры казахского народа. Труды ученого явились крупным вкладом в изучение истории, 
культуры и китературы народов Средней Азии. Его творческое наследие выходит за рамки национальной принаАлежности и может представлять большой интерес в мировой науке в контексте межкультурной коммуникации и межкультурного образования. ПреАставлены виды и особенности функционирования казахских национальных реалий, а также некоторые лингвокультурологические особенности в работах Ш. Уалиханова. Реалии представляют собой слова и словосочетания, называющие предметы, явления, объекты, характерные Аля жизни, быта, культуры, социального и исторического развития одного народа и малознакомые мибо чуждые Аругому народу, выражающие национальный и (или) временной колорит, не имеющие точных соответствий в Аругом языке. Особое внимание акцентируется на основной черте реа^ии - колорите, который передает особенности исторической эпохи, культуры, национального характера, местности.

Кмючевые слова: мингвокультурологические особенности, реалии, межкультурное образование, язык, культура.

\section{Introduction}

One of the main directions of a modern multicultural society evolution is the study and preservation of cultural and linguistic heritage, which can be considered in its entirety - in the context of literary criticism, linguistic studies, philosophy, cultural studies, psychology, pedagogy.

The language ideology and language policy of modern Kazakhstan is a balance of multilingualism and internationalization. State regulation of national-linguistic relations and linguistic processes in theory and practice is solved in the form of a "socio-cultural version" of the policy of multiculturalism and linguistic pluralism: all languages are supported, the linguistic rights of their speakers are protected, bilingualism / multilingualism is encouraged in education and media. (Suleimenova, 2011).

Thestudy of theworksbyoneoftherepresentatives of the Kazakh intelligentsia of the XIX - early XX centuries Sh. Ualikhanov from the point of view of the linguistic and cultural content, the reflection of the multicultural and multilingual development of society in the text and the description of the author's personality and consciousness actualizes the issues related to the preservation of the cultural heritage of the Kazakhs and its representation in the world. This makes it possible to revive the people's diplomacy presented in the sources, and through the works of prominent representatives of the Kazakh intelligentsia to acquaint the world community with the life of the inhabitants of Central Asia, their history, value guidelines through the study of language development. As noted by A.M. Karchalov, the works of Sh. Ualikhanov have a rich basis and a high scientific value, allowing to learn significant information on traditional clothing, crafts, nomadic economy and much more (Karchalova, 2019).

The huge part of cultural, national, and individual material in the works of Sh. Ualikhanov re- quires a careful study, since they are the carriers of national and historical flavor, which is expressed through ethno cultural realia and characterizes a certain linguocultural community, and also contains concepts of the global world, understandable to everyone, regardless of belonging to any culture. The events that took place after the collapse of the USSR require the study and analysis of the historical and linguistic interaction of languages and cultures that were united by the Russian language (Asanbay, 2005). O.N. Skubeydina writes that the language "contributes to the creation and accumulation of cultural values, the preservation of all ethnic layers of the national type of culture. It is only thanks to the language that it becomes possible to cognize the historical experience of previous eras, since only language preserves and accumulates all the values of national culture"(Skubeydina, 2002: 8).

O. Suleimenov points out that it seems expedient to develop a new direction, the purpose of which will be to describe the mutual influence and interaction of cultures and languages in a modern multicultural society (Suleimenov, 2013).

Shokan Ualikhanov was an orientalist, a geographer, an ethnographer, a literary critic, and a member of the Russian Geographical Society. He wrote his works in Russian. This gave him the opportunity to gain fame in wide scientific circles. Sh. Ualikhanov's works were highly appreciated by prominent scientists and made a major contribution to the study of the history, culture and literature of the peoples of Central Asia. He left an indelible mark on the history and culture of many peoples. His name has become the national pride of the Kazakh people, and his creative heritage in its significance goes far beyond the national boundaries. The scientist has accumulated a lot of valuable historical and ethnographic information, folklore material, and cultural realias. In this regard, the works of Sh. 
Ualikhanov are an unexplored field for scientistslinguists and educators-researchers.

\section{Experiment}

The scientific works by Sh. Ualikhanov make the subject of the study. For the analysis, we used such well-known essays and articles by the scientist as "Notes on the Kirghiz", "On the genres of Kazakh folk poetry", "Diary of a trip to Issyk-Kul", "Essays in Dzungaria", "Traditions and legends of the great Kyrgyz-Kaisak horde", "Tenkri", "On the forms of Kazakh folk poetry","Kyrgyz genealogy", "Draft materials about the Kirghiz",'Description of the way to Kashgarand back to the Alatav district","On Islam in the steppe"and other works. They became the basis of fundamentally new views on Kazakhs, their culture and literature and were highly appreciated by many scientists.

The aim of the study is to investigate and popularize the historical, cultural, linguocultural heritage of the prominent Kazakh researcher Sh. Ualikhanov through translating a number of his works into English in the context of the transformation of the intercultural aspect of modern education in Kazakhstan and in the world.

The study of the works by Sh. Ualikhanov actualizes the issues related to the preservation of the cultural heritage of the Kazakhs and its representation in the world. Historical and cultural heritage has enormous pedagogical capacity in the development of a person's national and cultural identity in the context of intercultural education. Today, we observe an actualization of intercultural education, which is aimed, first of all, at deepening the knowledge of students about culture and instilling the values necessary for full functioning in a modern multicultural society.

The content of the study corresponds to the conceptual provisions of the state policy of the Republic of Kazakhstan, pledged in the Strategy "Kazakhstan-2050: "A new political course of an established state", aimed at the development of our country as a society of progressive views, the basis for which should be provided by the intelligentsia. The Leader of the Nation N.A. Nazarbayev points out that the intelligentsia should become the leading force in strengthening national values at the stage of an established state, should play a key role in designing a mental, ideological model of the country's future (Nazarbayev, 2012). This understanding of the role of the intelligentsia is largely based on the traditions of the Kazakh people, who for centuries put the issues of human values development in the first place. The content of the research is also based on the key points of the Concept of cultural policy of the Republic of Kazakhstan (Concept, 2014). The Concept emphasizes the importance of the cultural development of Kazakhstan, which should be aimed primarily at preserving, researching and transmitting cultural heritage. Cultural heritage is an integral part of national identity which lies at the heart of the successful development of society and the state.

One of the main principles of intercultural education is intercultural understanding, which develops primarily on the basis of understanding the national culture. The works of Kazakh educators, which reflect the originality of the Kazakh people's culture, have great pedagogical potential in the formation of national and cultural identity and the development of intercultural communication. In this regard, the development of projects to preserve the richness of the cultural heritage of the Kazakh people and their popularization, contributing to the development of intercultural communication, is of particular importance.

The works of Sh. Ualikhanov and his ideals of enlightenment are an invaluable contribution to the development of language and culture, which deserves serious studies. Popularization of Sh. Ualikhanov's works as a cultural heritage of our country will make it accessible to the world community. The linguistic and cultural features of his works are the historical and cultural code, implemented in the original text, as well as the realias that reflect national culture and traditions. In addition, scientists from various fields of knowledge, researchers interested in studying the culture of Kazakhstan, will be able to determine the forms of interaction and mutual influence of the Kazakh culture with other world cultures.

The research methodology is based on the basic methods of empirical and theoretical and experimental levels. As part of the study, the method of continuous sampling was used to select realias that the scientist first used in his scientific works, geographical essays, letters, folklore and ethnographic articles.

Realias are names inherent only to certain nations and peoples, objects of material culture, facts of history, state institutions. They may present the names of national and folklore heroes, mythological creatures, etc. Comparing languages, we find in each of them such phenomena that have no correspondence in others (Breus, 2011: 98).

In realia, the closeness between language and culture is most clearly manifested: the emergence of new realia in the material and spiritual life of society leads to the emergence of new realias in the 
language, and the time of the emergence of new realia can be established quite accurately, since the vocabulary is sensitive to all changes in social life (Latyshev, 1981: 188).

The realias were divided according toV.V. Vinogradov's classification. The scientist explains that realias are lexical units that reflect background information. The background information by V.V.Vinogradov is "socio-cultural information, characteristic only for a particular nation or nationality, mastered by their representatives only and reflected in the language of this national community" (Vinogradov, 1977).

In the course of the study, it was revealed that the works of Sh. Ualikhanov contain the realias of the political system and social life, religious and mythological realias, everyday realias, natural geographic realias.

Geographic realias include the names of objects of physical geography (steppe); names of objects associated with human activities (aul); endemic names (kunan) and so on. The examples are realias denoting names of objects or names.East Turkestanis the historical name of the region in Central Asia; The Astrakhan Khanate is a feudal state that arose at the end of the 15th century on the ruins of the Golden Horde. It should be noted that these realias are accompanied by the author'scomments. The phrase Kok Orda(kok means blue in English, Blue Horde) has the author's explanation as the Eastern part or the left wing of the Golden Horde (Dzhuchi ulus), located on the territory of Western Siberia and Kazakhstan.

The fact that the Kazakhs led a nomadic way of life and their main occupation was cattle breeding, once again confirms the presence of realias associated with the main type of living activity and features of the itinerant life. Many realias may be absolutely incomprehensible to a modern or a foreign reader, so the author gives the necessary explanations. Thus, the word aryk could be represented as ditch, canal (canal), but at the same time, the reader could not imagine this structure as an irrigation canal in Central Asia. Ayaguz is a city through which in the past there was a lively caravan trade. The wordyantakis a forage plant growing in the desert regions of Central Asia. The names of animals depend on their age and gender. For example, bura is a male-camel; nar, that is, one-humped camel, dromedary; kunanmeans not just a horse, but a three-year-old horse; tokhtymeans a one-year-old ram, also requires a special understanding.

The main specificity of ethnographic realias is the preservation of the meaning that they had in a certain historical period of time in a specific geographic space.

Ethnographic realias include concepts belonging to the life and culture of the people: everyday life (saba); labor (kuryk); names of concepts of art and culture (batyr, dombra); ethnic concepts (zhuz, naimans); measures and money (sazhen, dinar); auliyemeaning saint.

The realias of the political system and social life also have a historical specificity associated with the socio-political system of the nomads. Obviously, many of the realias of this type are no longer used in their original meaning. For example, bek is a title of nobility, denotes a feudal ruler, head of a clan and tribe, corresponds to the titles of a prince, a ruler, a lord; albanmeans a tribute; dzesyr means a slave; bukaul, that is the manager of the khan's dinner.

It should be noted that realias of all types can be divided into 3 groups:

1) realias that have fully retained their semantic properties;

2) realias that partially retained their semantic properties and acquired new meanings;

3) realias that have fallen out of use in the modern context.

The first group includes the following wordsaimak (district, region) designates a modern administrative unit;arumeaningpure, immaculate, kyzgaldakis a wild poppy, coprose, makalis a proverb, afolksay, zan meaning a law which now coincide with their original meanings.

The second group is represented by realias that have retained their original meaning and received a new semantic content that corresponds to modern realias. Here are some examples. The word kosh, that is, aul, which is on the way in the process of nomadism, kosh - aulmeaning moving from one nomadic camp to the other, is rarely used today. The word zhaylyau, which means a summer settlement of nomads, does not fully correspond to the original historical meaning, all the way with a change in the social system.

The word kozhe is absolutely incomprehensible to a foreign reader, and needs to be explained: "In winter, Kaisaki take a drink made of flour mixed with hot water, fermented in tubs and called skin; milk is added to improve the taste.(Sh. Ualikhanov). Currently, kozhe also denotes a milk drink, but among young people it is more likely associated with nauryz kozhe, which is a ritual soup of national cuisine for the Nauryz holiday.

The word dzhigit originally meant a skillful and valorous horseman, and conveyed the brilliant skills of a good horseman. However, today this 
word is used figuratively meaning a goodboy, well done.

The word amanat is translated from the Kazakh language as a hostage. Nowthe word has a broader meaning, denoting universal human values at the present time. The word mufti, meaning the main judge of a Shariacourt pronouncing a decision on religious and legal issues, is used in a religious context only.Chalakazaksethnically are the descendants of the Kazakhs, having a mixed origin, they are characterized by a semi-sedentary lifestyle. Today this word is pronounced shalakazakhi and is used in relation to representatives of Kazakh nationality who has poor Kazakh language proficiency and poor knowledge of the national culture and traditions, the word is mainly used in a humorous manner.

Some realias have acquired new phonetic and spelling forms. For example, shabtolu, which is translated as peach, is spelled shabdaly; sharkrama (waterfall) has transformed into sakyrama.

The third group undoubtedly includes geographical realias denoting historical names. For example, Ak Orda(White Horde in English) is a feudal state that existed in the middle of the XIII the first third of the XV centuries; Kazan Khanateis a feudal state in the Middle Volga region; Kok Orda(Blue Horde)is the Eastern part or left wing of the Golden Horde (ulus Dzhuchi), located on the territory of Western Siberia and Kazakhstan.

In addition, this includes the realias associated with the peculiarities of the social and religious structure of that time. For example, atalyk is the position of the regent, court uncle, educator of the khan's sons.

It should also be noted the ancient dzhaurunchiare fortune-tellers on the lamb shoulder, calcined on fire. The fortuneteller predicts the future by the shape of the cracks that form on the shoulder blade during its burning Dzhaurunchi - Predictors of lamb shoulder bone, hardened in the fire. Soothsayers predict the future in the form of cracks, which are formed on the blade, in the process of burning.

In the work Traces of shamanism among the Kirghiz Sh. Ualikhanov gives an explanation about the art of Kazakh baksy, about the healing functions of their music. To convey the functional role of reality, he writes that the baksyare predictors of Kyrgyz people... and they speak all their predictions on behalf of their spirits, they could "communicate" with arvakhs (spirits of deceased ancestors), theywere healers, sorcerers, but at the same time talented musicians and actors. Sh. Ualikhanov figuratively and vividly represents the art of shamans. This is how he described the acting abilities of the baksy: "The signs of the baksy are the following: during the game, he puts a saber in his stomach, releases it to his throat, licks a redhot iron, hits himself with all his might in the chest with an ax, and all this is accompanied by playing the kobyz (two-string bowed instrument), which belonged to Auliye Korkyt, and singing called sarn (sarn)"(Valikhanov, 1961: 475).

The profession of shamans, in comparison with akyns, singers and musicians, was not widespread in the Kazakh steppe. Assessing the complexity of this "profession" Sh. Ualikhanov notes that "not everyone can be a shaman, just as not everyone of us can be a poet" (Valikhanov, 1961: 199). A vivid, detailed description of the behavior of shamans, their kobyz playing, their unusual attire and attributes not only shows the extraordinary knowledge of Sh. Ualikhanov in the field of folk art, but also his ability to preserve the national and historical flavor of the conveyed realias.

When describing a realia that is new for the reader, he skillfully chooses the place and presentation of the unfamiliar realias in the text. These words unfamiliar to the reader are presented in such a way that they allow one to perceive what is being described, feeling at the same time that specific "scent of alienation", a characteristic local or national historical flavor.

\section{Results and discussion}

The deep or additional meaning of realia requires a careful study and explanation in their native language and when translated into other languages. Realias, reflecting the specifics of the national culture, may have connotations that are not always available to a representative of a foreign language culture. The disclosure of national and cultural associations in the multicultural educational space is especially important.

The scientific novelty of the research lies in the fact that for the first time the linguoculturological features in the works by Sh. Ualikhanov are comprehensively considered, the relevance of a holistic approach to the national historical and cultural content in the context of intercultural communication and education is substantiated.

The research results will correspond to the social demand in the field of education, intercultural interaction, education of a multicultural personality, respecting the culture of all peoples. In addition, the results are designed to enrich modern language education from the perspective of its intercultural and communicative 
paradigm, internationalization; to contribute to the development of the intellectual potential of the country on the basis of familiarizing its citizens with the values of language and culture.

The main expected result is the study of a wide range of theoretical and practical issues related to understanding the diversity of ways and forms of interaction and mutual influence of the Kazakh, Russian and English languages in the context of multiethnic, multilingual and multicultural Kazakhstan, defining the essence of the Kazakh model of a multilingual personality, the possibilities of preventing language conflicts. In general, this will allow developing ethno political, socio-economic and ethno-linguistic foundations for further improving the Kazakhstani development model and state structure in the context of strengthening Kazakhstan's positions in the world community and constructive international interaction.

\section{Conclusion}

The development of language, literature, culture, the preservation of values and the spiritual heritage of the nation, as well as introducing to the world community the cultural and spiritual wealth of the Kazakh people through the works of the famous Kazakh educator Sh. Ualikhanov in order to actualize modern education is of fundamental importance.

In this regard, the study and popularization of the life and work of the prominent Kazakh scientist and educator Sh. Ualikhanov is aimed at interaction and integration of the national and world cultural environments. The study of the works by Sh. Ualikhanov will contribute to solving practical problems of multicultural education.

The variety of national Kazakh realias in the works by Sh. Ualikhanov can serve as a starting point for a further study of customs, traditions and other cultural features of the Kazakh people based on other sources.

Shokan Ualikhanov's works play an important role in bringing together the cultures of different peoples and in the formation of the Eurasian culture of modern Kazakhstan. The works by Sh. Ualikhanov are of great interest for the world community from a scientific and cultural point of view, since it presents a deep study of the steppe civilization, shows its historical significance.

This research is funded by the Science Committee of the Ministry of Education and Science of the Republic of Kazakhstan (Grant № AP08957331)

\section{Литература}

Сулейменова Э.Д. Языковые процессы и политика. - Алматы: Қазақ университеті, 2011. - 117 с.

Карчалова А.М. Этнография казахов в трудах Чокана Валиханова // Алтайский текст в русской культуре. - Барнаул: Алтайский государственный университет. - Вып. 8. - 2019. - С. 218-223.

Қазақстан: табысқа жету тарихы әлемдік қоғамдастық көзімен / Редактор Р. Асанбай. - Алматы: Таймас Баспа Үй, 2005.

Скубейдина О.Н. Язык и национальный тип культуры: автореф. дисс. ... к. филос. н. - Ростов н/Д, 2002. -23 с.

Сулейменов О. Код слова. - Алматы: ОФ Литературный альянс, 2013. - 88 с.

Послание президента - лидера нации Н.А. Назарбаева народу Казахстана «Стратегия «Казахстан-2050»: новый политический курс состоявшегося государства»//http://www.akorda.kz/ru/page/page_215738_poslanie-glavy-gosudarstva-nursultananazarbaeva-narodu-kazakhstana

О концепции культурной политики Республики Казахстан: Указ Президента Республики Казахстан от 4 ноября 2014 года № 939.

Бреус Е.В. Теория и практика перевода с английского языка на русский. Часть 1. - М.: УРАО, 2001. - 104 с.

Латышев Л.К. Курс перевода (эквивалентность перевода и способы ее достижения). - М.: Международные отношения, 1981. $-247 \mathrm{c}$.

Виноградов В.В. Об основных типах фразеологических единиц в русском языке // Избранные труды. Лексикология и лексикография. - М., 1977. - С. 140-161.

Валиханов Ч.Ч. Собр. соч. в 5 т. - Т. 1. - Алма-Ата: Изд-во АН Каз. ССР, 1961. - 777 с.

\section{References}

Breus Ye.V. (2001). Teoriya i praktika perevoda s angliyskogo yazyka na russkiy [Theory and practice of translation from English into Russian.]. M: URAO. 104 p. (In Russian).

Karchalova A.M. (2019). Etnografiya kazakhov v trudakh ChokanaValikhanova. [Ethnography of Kazakhs in the works of ChokanValikhanov] Altayskiy tekst v russkoy kul'ture. Barnaul: Altayskiy gosudarstvennyy universitet. 218-223 p. (In Russian).

Kazakhstan: Tabyska zhetu tarikhy alemdik kogamdastyk kuzimen. [Kazakhstan: Success story through the eyes of the world community]. (2005). Editor R. Asanbai. Almaty:Taimas Publishing House. (In Kazakh). 
Latyshev L.K. (1981). Translation course (translation equivalence and the ways to achieve it). M: International relations. 247 p. (In English).

Nazarbayev N.A. (2012). Address by the President of the Republic of Kazakhstan, Leader of the Nation "Strategy "Kazakhstan-2050": a new political course of the established state"//http://www.akorda.kz/ru/page/page_215738_poslanie-glavygosudarstva-nursultana-nazarbaeva-narodu-kazakhstana. [Electronic resource]. (In English).

O kontseptsii kul'turnoy politiki Respubliki Kazakhstan. [On the Concept of cultural policy of the Republic of Kazakhstan]. Decree of the President of the Republic of Kazakhstan dated November 4, 2014, No. 939. (In Russian).

Skubeidina O.N. (2002). Yazyk I natsional'nyy tip kul'tury. [Language and the national type of culture]: diss.... candidate of philosophical sciences. Rostov-na-Donu. 23 p. (In Russian).

Suleimenova E.D. (2011). Yazykovyye protsessy i politika.[Language processes and policy]. Almaty: Kazakh University. 117 p. (In Russian).

Suleimenov O. (2013). Kodslova. [The code of the word]. Almaty: OFLiterary Alliance. 88 p. (In Russian).

Valikhanov Ch.Ch. (1961).Sobr. soch. v 5 t., t. 1. [Collection of works in 5 volumes. V. 1] Alma-Ata: Publishing House AS Kaz. SSR. 777 p. (In Russian).

Vinogradov V.V. (1977) Ob osnovnykh tipakh frazeologicheskikh yedinits v russkom yazyke [On the main types of phraseological units in the Russian language]. Leksikologiya i leksikografiya. Moscow. 140-161 p. (In Russian). 